\title{
Acacia (Samanea saman (JACK) MERR) pods as feeds for broilers
}

\author{
Barcelo Patricia M., Libong Juanito E., Coloma Evalyn T. \\ Don Mariano Marcos Memorial State University, Bacnotan, La Union, Philippines \\ Email address: \\ pmbarcelo56@yahoo.com (Barcelo P. M.), barcelopatricia@rocketmail.com (Barcelo P. M.)
}

\section{To cite this article:}

Barcelo Patricia M., Libong Juanito E., Coloma Evalyn T.. Acacia (Samanea Saman (JACK) MERR) Pods as Feeds for Broilers. Agriculture, Forestry and Fisheries. Vol. 2, No. 6, 2013, pp. 235-238. doi: 10.11648/j.aff.20130206.16

\begin{abstract}
This study was conducted to determine the performance of broilers fed with $0 \%$ to $35 \%$ Samanea saman (JACK) $M E R R$ pod meal in the formulated rations in terms of gain in weight, feed consumption, feed conversion efficiency, dressing percentage, per cent liver weight and profit above feed cost. Samanea saman (JACK) MERR pods were dried for 3-5 days, ground then mixed with the other feed ingredients to produce isocaloric and isonitrogenous rations. Commercial mash served as the control. Based from the results of the study, Samanea saman (JACK) MERR pod meal at $0 \%$ to $35 \%$ of the formulated rations produced comparable gain in weight, feed consumption, feed conversion efficiency, dressing percentage, liver weight and profit above feed cost of birds. Results also revealed that the performance of birds fed with the formulated rations were comparable to the performance of birds fed with commercial ration. Samanea saman (JACK) MERR pod meal could therefore substitute corn in broiler rations.
\end{abstract}

Keywords: Samanea Saman (JACK) MERR Pod Meal, Formulated Rations, Broilers, Performance

\section{Introduction}

Broiler production is a viable sector of the poultry industry in the Philippines. Broilers are efficient converters of feed into meat. Broiler production $(27.00 \%)$ ranked second to swine $(59.00 \%)$ in terms of volume of meat produced in which the volume of production of the other animals ranged from $1 \%$ to $7 \%$ only ${ }^{[3]}$. Since poultry meat contributes a considerable amount to the total meat requirements in the Philippines, more focus on the economical production of broilers is desired to bring cheap poultry meat to consumers and help bridge the protein gap in the Filipino diet.

The supply of feed ingredients particularly the animal protein feed sources have become insufficient and expensive in broiler production. The high cost of feeds, which is 70 to $80 \%$ of the total cost of production results to high cost of poultry meat products. At present, emphasis is given on the discovery of high-grade protein feedstuffs which are relatively cheap and locally available to substitute feed ingredients that are imported.

Fish meal and soybean oil meal are imported ingredients for broilers. Corn is the chief grain feed to poultry and it is unexcelled for this purpose when properly used. Though corn is produced locally, the production of this commonly used ingredient in poultry rations is not enough due to climate change that has affected the production of crops like corn. Just recently, the damage in crops brought by typhoons has reached millions. In addition, corn supply become scarce during the dry season. Because of this, alternative substitute to corn like the Samanea saman (JACK) MERR pod meal that is abundant during the dry season has been studied.

Acacia or Samanea saman (JACK) MERR belongs to the Family Leguminasea which is a good source of protein and energy. The Samanea saman (JACK) MERR pod meal contains about $13.75 \%$ protein, 89.25 to $1.175 \%$ dry matter, 2.98 to 1.63 ether extract, 2.19 to $14.54 \%$ crude fiber, 0.23 to $3.27 \%$ ash and 6.44 to $55.67 \%$ nitrogen extract ${ }^{[2]}$. Ruminants could eat the leaves and the pods could be tapped as sources of feeds for ruminants during the drought periods when feeds are scarce ${ }^{[1,2]}$. As such, the potential of this feed ingredient as a feed ingredient for poultry has been investigated.

This study was conducted to determine the performance of broilers fed with different levels of Samanea saman (JACK) $M E R R$ pod meal. Specifically, it aims to determine the gain in weight, feed consumption, feed conversion efficiency, dressing percentage, percent liver weight and profit above feed and stock cost of broilers fed with varying levels of Samanea saman (JACK) MERR pod meal in the formulated rations. 


\section{Methodology}

\subsection{Preparation of the Samanea Saman (JACK) MERR Pod Meal}

The Samanea saman (JACK) MERR pods were gathered along the vicinity of the University campus. These were dried for one month and then ground. The seeds were also ground and form part of the Samanea saman (JACK) MERR pod meal. After grinding, the different levels of Samanea saman (JACK) MERR pod meal were mixed to other ingredients following the corresponding amounts specified in each treatment.

Table 1 presents the composition of the formulated rations using Samanea saman (JACK) MERR pod meal as feed ingredient in broiler rations. Corn and soybean oil meal were balanced to meet the nutrient requirements of the birds.

Table 1. The formulated rations with varying levels of Samanea saman (JACK) MERR pod meal

\begin{tabular}{lllll}
\hline Feed Ingredients & T1 & T2 & T3 & T4 \\
\hline Yellow corn & 37.55 & 9.95 & 8.00 & 3.00 \\
Soybean oil meal & 18.00 & 16.55 & 17.55 & 17.55 \\
Fish meal & 10.00 & 10.00 & 10.00 & 10.00 \\
Rice meal & 28.00 & 28.00 & 28.00 & 28.00 \\
Copra meal & 5.00 & 5.00 & 5.00 & 5.00 \\
V-min Premix & 0.25 & 0.25 & 0.25 & 0.25 \\
Dicalcium Phosphate & 1.00 & 1.00 & 1.00 & 1.00 \\
Salt & 0.10 & 0.10 & 0.10 & 0.10 \\
Methionine & 0.10 & 0.10 & 0.10 & 0.10 \\
Samanea saman (JACK) & & & & \\
MERR pod meal & 0.00 & 25.00 & 30.00 & 35.00 \\
Total & $\mathbf{1 0 0 . 0 0}$ & $\mathbf{1 0 0 . 0 0}$ & $\mathbf{1 0 0 . 0 0}$ & $\mathbf{1 0 0 . 0 0}$ \\
Nutrient Composition & & & & \\
Crude Protein & 19.74 & 20.12 & 20.58 & 20.59 \\
Metabolizable Energy & 2000 & 1200 & 1400 & 1600 \\
Calcium & 0.92 & 0.97 & 0.90 & 0.90 \\
Phosphorus & 0.95 & 0.89 & 0.88 & 0.87 \\
\hline
\end{tabular}

\subsection{Experimental Design}

A total of seventy-five (75) three-week old broiler chicks were used in the study. The broiler chicks were distributed at random in five treatments using the Randomized Complete Block Design (RCBD). Each treatment was replicated three times and each replicate had five birds.

The treatments used were as follows:

$$
\begin{aligned}
& \mathrm{T}_{1}-\text { No Samanea saman (JACK) MERR pod meal } \\
& \mathrm{T}_{2}-25 \% \text { Samanea saman (JACK) MERR pod meal } \\
& \mathrm{T}_{3}-30 \% \text { Samanea saman (JACK) MERR pod meal } \\
& \mathrm{T}_{4}-35 \% \text { Samanea saman (JACK) MERR pod meal } \\
& \mathrm{T}_{5}-\text { Commercial ration (Control) }
\end{aligned}
$$

\subsection{Management Practices and Data Gathered}

Before the arrival of the chicks, the brooder house was cleaned thoroughly and disinfected with Creoline solution. After disinfecting, the brooder house was allowed to stand for two days to eradicate the odor. The cages were covered with empty sacks to protect the chicks from draft. The flooring was provided with newspapers as beddings. Clean, fresh and medicated water was provided to the birds at all times. Antibiotics were also added to the water to prevent possible disease infection. Feeds were given ad libitum.

Routinary management practices in broiler production were done. Data gathered were initial weight, weight at 45 days, feed consumption, feed conversion efficiency, dressing percentage, liver weight and profit above feed cost.

\section{Results and Discussion}

\subsection{Feed Consumption and Feed Conversion Efficiency of Birds}

The feed consumption reflects the palatability and acceptability of the formulated rations. On the other hand, the feed conversion efficiency reflects the amount of feeds to produce a kilogram gain in weight.

The total feed consumption and feed conversion of birds as affected by varying levels of Samanea saman (JACK) MERR pod meal in the formulated rations is shown in Table 2.

Table 2. Feed consumption and feed conversion efficiency of birds fed with varying levels of Samanea saman (JACK) MERR pod meal (kg)

\begin{tabular}{lcc}
\hline Treatment & Feed Consumption & Feed Conversion Efficiency \\
\hline $\mathrm{T}_{1}-0 \%$ Samanea saman $(J A C K)$ MERR pod meal & 2.07 & 2.27 \\
$\mathrm{~T}_{2}-25 \%$ Samanea saman $(J A C K)$ MERR pod meal & 2.03 & 2.56 \\
$\mathrm{~T}_{3}-30 \%$ Samanea saman $(J A C K)$ MERR pod meal & 1.97 & 2.52 \\
$\mathrm{~T}_{4}-35 \%$ Samanea saman (JACK) MERR pod meal & 1.87 & 2.09 \\
$\mathrm{~T}_{5}-$ commercial mash & 2.10 & 2.06 \\
\hline
\end{tabular}

Birds fed with commercial mash had the highest feed consumption with a mean of $2.10 \mathrm{~kg}$ while the least intake was obtained by the birds fed with $35 \%$ Samanea saman (JACK) MERR pod meal of $1.87 \mathrm{~kg}$. This implies that substitution of Samanea saman (JACK) MERR pod meal to corn at $0 \%$ - to $35 \%$ did not affect the feed consumption of the birds. It also implies that the formulated rations had comparable palatability to the commercial ration that could be due to the rations which were isocaloric and isonitrogenous. Although there are anti-nutritional properties of Samanea saman (JACK) MERR like tannic acid,licorie, the 
sweet-smelling component of the Samanea saman (JACK) $M E R R$, might have also added palatability to the formulated rations.

The feed conversion efficiency of birds fed with varying levels of Samanea saman (JACK) MERR pod meal ranged from 2.06 to 2.56 which means that the amount of the formulated rations to produce a kilogram gain in weight was within the accepted range of 2.50 to $3.5 \mathrm{~kg}$. Results could be due to the comparable nutrients of the formulated rations to the commercial mash that had a nutrient analysis of $20 \%$ crude protein as indicated in its label.

\subsection{Gain in Weight of Birds (kg)}

As shown in the Table 3, the gain in weight of birds fed with the formulated rations with $0 \%$ to $35 \%$ Samanea saman (JACK) MERR pod meal to substitute corn were comparable. The gain in weight of birds fed with varying levels of Samanea saman (JACK) MERR pod meal was also comparable with the gain in weight of birds fed the commercial mash. This implies that Samanea saman (JACK) $M E R R$ pod meal can substitute corn up to $35 \%$ without affecting the gain in weight of birds.

The maximum level of Samanea saman (JACK) MERR pod meal consumption in goats was $75 \%$ in addition to Pennisetum purpureum to produce comparable results ${ }^{[2]}$ indicating that there is a maximum level of acacia pods in goats. The results of this study may imply that the level of Samanea saman (JACK) MERR pod meal consumption in broilers could be increased in future studies to determine the maximum level of Samanea saman (JACK) $M E R R$ pod meal that could be incorporated in the diets of broilers. The utilization of Samanea saman (JACK) MERR pod meal, especially if it is abundant in the locality, will reduce the cost of producing broilers.

Table 3. Gain in weight of birds fed with varying levels of Samanea saman (JACK) MERR pod meal $(\mathrm{kg})$

\begin{tabular}{ll}
\hline Treatment & $\begin{array}{l}\text { Gain In } \\
\text { Weight }\end{array}$ \\
\hline $\mathrm{T}_{1}-0 \%$ Samanea saman (JACK) MERR pod meal & 1.12 \\
$\mathrm{~T}_{2}-25 \%$ Samanea saman (JACK) MERR pod meal & 0.88 \\
$\mathrm{~T}_{3}-30 \%$ Samanea saman (JACK) MERR pod meal & 0.78 \\
$\mathrm{~T}_{4}-35 \%$ Samanea saman (JACK) MERR pod meal & 0.89 \\
$\mathrm{~T}_{5}-$ commercial mash & 1.09 \\
\hline
\end{tabular}

3.3. Dressing Percentage and Percent Liver Weight of Birds Fed with Varying Levels of Samanea saman (JACK) MERR Pod Meal (Kg)

Table 4 shows the dressing percentage of birds as affected by the different levels of Samanea saman (JACK) MERR pod meal. As shown in Table 4, the dressing percentage of birds fed with varying levels of Samanea saman (JACK) MERR pod meal in their rations were comparable to those fed with the commercial mash.
Table 4. Dressing percentage and per cent liver of birds fed with Samanea saman (JACK) MERR pod meal (\%)

\begin{tabular}{lll}
\hline Treatment & $\begin{array}{l}\text { Dressing } \\
\text { Percent }\end{array}$ & $\begin{array}{l}\text { Percentage } \\
\text { Liver }\end{array}$ \\
\hline $\begin{array}{l}\mathrm{T}_{1}-0 \% \text { Samanea saman (JACK) MERR pod } \\
\text { meal }\end{array}$ & 89.65 & 2.03 \\
$\begin{array}{l}\mathrm{T}_{2}-25 \% \text { Samanea saman (JACK) MERR pod } \\
\text { meal }\end{array}$ & 92.28 & 2.04 \\
$\begin{array}{l}\mathrm{T}_{3}-30 \% \text { Samanea saman (JACK) MERR pod } \\
\text { meal }\end{array}$ & 92.02 & 1.79 \\
$\begin{array}{l}\mathrm{T}_{4}-35 \% \text { Samanea saman (JACK) MERR pod } \\
\text { meal }\end{array}$ & 90.86 & 1.93 \\
$\mathrm{~T}_{5}-$ commercial mash & 92.27 & 2.21 \\
\hline
\end{tabular}

Birds fed with commercial mash had the highest percent liver with a mean of $2.21 \%$, while the birds fed with $30 \%$ Samanea saman (JACK) MERR pod meal had the lowest with a mean of $1.79 \%$.Per cent liver was computed as the weight of the liver divided by the carcass weight multiplied by 100 .

Arora, et al. ${ }^{[1]}$ stated that the anti-nutritional factors present in many fodder trees are hydrocyanic, coumarin, oxalates and nitrates that may limit the utilization of their nutrients. The liver enlarges if there are toxic elements present in their rations. However, it was observed that the per cent liver of birds were unaffected, hence, it can be concluded that the amounts ofSamanea saman (JACK) $M E R R$ pod meal incorporated in the formulated rations were within the tolerable levels by the birds.

\subsection{Profit above Feed, Medicine and Stock Costs (Pesos)}

The profit above feed, medicine and stock costs of broilers as affected by different levels of Samanea saman (JACK) $M E R R$ pod meal in the ration is presented in Table 5.

Table 5. Mean profit above feed, medicine and stock costs of birds fed with varying levels of Samanea saman (JACK) MERR pod meal (Pesos).

\begin{tabular}{ll}
\hline Treatment & Profit \\
\hline $\mathrm{T}_{1}-0 \%$ Samanea saman (JACK) MERR pod meal & 39.03 \\
$\mathrm{~T}_{2}-25 \%$ Samanea saman (JACK) MERR pod meal & 24.80 \\
$\mathrm{~T}_{3}-30 \%$ Samanea saman (JACK) MERR pod meal & 23.63 \\
$\mathrm{~T}_{4}-35 \%$ Samanea saman (JACK) MERR pod meal & 20.54 \\
$\mathrm{~T}_{5}-$ commercial mash & 33.93 \\
\hline
\end{tabular}

Birds fed with o\% Samanea saman (JACK) MERR pod meal had the highest profit of PhP 39.03 while the birds fed with $35 \%$ Samanea saman (JACK) MERR pod meal in the formulated ration had the lowest profit of $\mathrm{PhP} 20.54$.

\section{Conclusions and Recommendations}

This study was conducted to determine the performance of broilers fed with varying levels of Samanea saman (JACK) 
$M E R R$ pod meal in the formulated rations. The parameters to assess performance were gain in weight, feed consumption, feed conversion efficiency, dressing percentage, per cent liver and profit above feed, medicine and stock costs.

\subsection{Conclusions}

Based on the results of the study, the following conclusions were made:

1. Samanea saman (JACK) MERR pod meal up to $35 \%$ in the formulated rations had comparable effects on the gain in weight, feed consumption, feed conversion efficiency, dressing percentage, per cent liver and profit above feed, medicine and stock costs of birds;

2. The performance of birds fed with formulated rations with $0 \%$ to $35 \%$ Samanea saman (JACK) MERR pod meal were comparable to the performance of birds fed with the commercial ration.

\subsection{Recommendations}

Based on the findings of the study the following are recommended:

1. Samanea saman (JACK) MERR pod meal could substitute corn up to $35 \%$ in formulated rations.

2. Higher levels of Samanea saman (JACK) MERR pod meal could be tested in future studies to determine the maximum level of incorporation in broiler diets.

\section{References}

[1] ARORA, S. P., K. SINGH and R. C. CHOPRA. 1981. A case study on the calcium and phosphorous requirements of ruminants. Indian J. Dairy Science, (34): 4. pp. 424-427.

[2] BARCELO, P.M. and J.R. BARCELO. 2012. The potential of Samanea saman (JACK) MERR. Pods as Feeds for Goats. International Journal of Zoology Research. (2): 1. pp. 40-43.

[3] PHILIPPINE BUREAU OF AGRICULTURAL STATISTICS. 2010. 